\title{
Efficiency and effectiveness of vitamin C-substrate organo-mineral straight fertilizer in lettuce (Lactuca sativa L.)
}

\author{
Hyo-Seok Chae ${ }^{1 *} \mathbb{D}$, Hye-Ji Noh ${ }^{2}$, Woo Seung Song ${ }^{1}$ and Hyang-Hyun Cho ${ }^{1}$
}

\begin{abstract}
Mineral fertilizers are expensive and last only a relatively short time. Proper handling of fertilizers has a direct impact on crop quality and profitability. Currently, straight fertilizers are divided into types, A and B, based on the fertilizer's sedimentation properties when mixed. Therefore, to solve these flaws, we developed a vitamin C-substrate organomineral fertilizer, AGH-Ringer. This study consisted of a fertilizer equivalency test, which lasted 15 weeks of soil cultivation in a farm field, using lettuce (Lactuca sativa L.,'Jeok Chi Ma') with AGH-Ringer as a test fertilizer. This fertilizer was based on powder compound-type fertilizer r-Ringer and manufactured by chelating essential minerals with a vitamin C substrate to have NPK contents in a ratio of 18.9:14:4.0. In the onsite evaluation, the superiority of AGH-Ringer was demonstrated through an effect of growth stimulation in both aerial and rhizosphere parts of the plants at suitable soil temperatures. This fertilizer also increased yield, even in inadequate low-temperature conditions. In addition, AGHRinger increased the absorption and bioavailability of minerals in lettuce leaves at harvest. The mineral absorption ability showed a uniform pattern during the entire harvest period. It has been confirmed that AGH-Ringer, manufactured with vitamin $C$ as a substrate, is a fertilizer with excellent efficacy that increases growth and harvest simultaneously, solving the existing problems of chemical fertilizers such as sedimentation and lack of mineral absorptivity in nutrient solution systems.
\end{abstract}

Keywords: Straight fertilizer, Vitamin C (substrate), Organo-mineral fertilizer, Fertilizer efficiency

\section{Background}

Agriculture has a played a major role in the development of human civilization for a long time. In prehistoric times, humans formed clans and started cultivating plants as a food supply. Conventional agricultural systems can cause multifarious negative impacts on the environment such as inefficient use of water, large-scale land requirements, outflow of residual pesticides, and erosion with soil degeneration [1]. Therefore, over time, people have attempted to develop cultivation techniques for more efficient food production and environmental conservation. Representative examples include hydroponic farming and bio-farming using bio-inoculation. Hydroponic cultivation, which is an advanced cultivation technique,

${ }^{*}$ Correspondence: iseuli@gmail.com

1 HANIL BIOMED Inc., Gwangju 62363, Korea

Full list of author information is available at the end of the article has advantages such as increase in yield, continuous production throughout the year, and a need for only a small area for cultivation of many kinds of agricultural products [2]. On the other hand, management of this cultivation system and the supply of culture medium are expensive. Recently, some organic fertilizers have been reported to play an important role in plant growth and development through plant growth-promoting microorganisms that colonize the rhizosphere and interact with the plant [3-5]. However, these microbial inoculations are difficult to use due to the diversity of open-field applications and laboratory results.

The concentration range of inorganic elements that promote optimal growth in crops varies by nutrient type and crop species. Plant growth is optimal when essential elements are supplied properly. When the absorbed inorganic element is either insufficient or excessive, the growth of stems and roots is impaired [6,7]. In addition, 
total yield is proportional to the mineral uptake. Therefore, at present, highly concentrated mineral fertilizers are frequently used in the cultivation of all crops. These fertilizers cause serious leaching and infiltration of $\mathrm{N}$ and $\mathrm{P}$ into soil and surface water, and also are inconvenient to use due to sedimentation [8]. Because of these problems, fertilizer is divided into types A and B, and each can be supplied to the crop only after dissolution through a dedicated supply system.

In plants, the minerals from the soil solution traverse the plant roots via apoplastic and/or symplastic pathways to the stele. In some plant species, several cytotoxic minerals such as $\mathrm{Ca}, \mathrm{Mo}, \mathrm{Na}, \mathrm{Cd}$, and $\mathrm{Al}$ are retained in the roots or transported in a chelated form [9]. Organic minerals called chelated or proteinated minerals are formed when the mineral is joined with an organic ligand such as a protein or a specific amino acid [10]. These organic minerals promote the movement of minerals from root to shoot, which is inhibited by the exchange capability of the xylem cell [11]. As the most representative of antioxidants, vitamin $C$ is the most abundant water-soluble oxide in plant cells. It accumulates in chloroplasts and plays an important role in the balance between excess and absent free radicals in the plant cells [12]. In addition, because vitamin $C$ has an $\mathrm{OH}$ group that can bind to minerals, it is expected that the two molecules and mineral ions will have the ability to chelate through coordinate covalent bonding. In Korea, it has been reported that using vitamin C-substrate zinc as a feed additive enhances the intramuscular fat content of bovines, and selenium with chitosan and a fatty acid as a substrate induce an increase in yield and promotion of growth in tomato [13, 14]. These reports suggest that chelated mineral fertilizers or feeds have some utility value. Therefore, in this study, vitamin C was selected as substrate and a chelated mineral fertilizer was generated.

The aim of this study was to make an organic fertilizer using vitamin $C$ as a substrate that maximized the production of high-quality crops. Additionally, this fertilizer was expected to complement declination of body absorptivity, cohesion and sedimentation, necessity of a nutrient solution supply system, and accumulation of soil salt and environmental contamination, which will improve the convenience of use and profitability in farm cultivation.

\section{Methods}

\section{Plant material and test site}

Seedlings of the lettuce cultivar 'Jeok Chi Ma' (Lactuca sativa L.) were obtained from Hampyeung Nursery (Worya-myeon, Hampteong-gun, Korea) about 7 days after sowing. Test site management and evaluation during the whole test period were carried out at Sannaedeul Farm (Daejeon-myeon, Damyang-gun, Korea). Dried and crushed soil samples were used for chemical and physical analyses. The green (organic farming) standard range of soil chemical and physical properties were $\mathrm{pH}$ 6.5-7.0, organic matter $20-30 \mathrm{~g} / \mathrm{kg}$, phosphate (P) 250-400 mg/ $\mathrm{kg}$, potassium (K) $250-400 \mathrm{cmol}+/ \mathrm{kg}$, calcium (Ca) 6-7 $\mathrm{cmol}+/ \mathrm{kg}$, magnesium $(\mathrm{Mg}) 2.0-2.5 \mathrm{cmol}+/ \mathrm{kg}$, and soil electrical conductivity (EC) $0.0-2.0 \mathrm{dS} / \mathrm{m}$. The ground temperature was monitored weekly for the entire test period [15-23].

\section{Preparation of fertilizer}

The fertilizer r-Ringer (AceKorea Co., Korea), which is used in agricultural fields, was purchased and used as a control fertilizer treatment. The test fertilizer, AGHRinger (Hanil Biomed Co., Korea), was manufactured based on $r$-Ringer by simply mixing its components with vitamin C (Nam Yung Commercial Co., Ltd., Korea) as a substrate (Table 1). All experiments were performed by using the two fertilizers diluted to different concentrations.

\section{Experimental design and treatments}

There were four test groups, each group with 16 lettuce seedlings. The control group was drenched with only water, and the other two groups were drenched with water and $50 \mathrm{~mL}$ diluted r-Ringer (diluted 1/2000) or AGH-Ringer (diluted 1/500, 1/1000, or 1/2000) once per week.

\section{Chemical damage}

To investigate the damage caused to the plant by the concentration and treatment with each fertilizer, the number of tipburns and leaf deaths per seedling was counted 13 days after transplanting.

\section{Growth analysis before harvest}

Twenty-four days after transplanting, growth status and tissue density were examined through the plant height $(\mathrm{cm})$, stem diameter $(\mathrm{mm})$, leaf length $(\mathrm{cm})$, leaf width $(\mathrm{cm})$, leaf number (ea/plant), leaf diameter $(\mathrm{mm})$, chlorophyll concentration $(\mathrm{mg} / \mathrm{g} \mathrm{FW})$, root length $(\mathrm{cm})$, fresh weight (g/plant), and dried weight (g/plant).

\section{Crop yield}

The yield was measured during two periods after seedling transplant. These periods were defined based on ground temperature: suitable low temperature $\left(14.6-18{ }^{\circ} \mathrm{C}\right.$, weeks 1-7) and inadequate low temperature (10.3$12.1{ }^{\circ} \mathrm{C}$, weeks $\left.8-15\right)$. Each test group consisted of 16 seedlings and was repeated three times. 
Table 1 Component of fertilizers

\begin{tabular}{|c|c|c|c|c|}
\hline \multirow[t]{2}{*}{ Feed materials } & \multicolumn{2}{|c|}{ Control fertilizer (r-Ringer) } & \multicolumn{2}{|c|}{ Test fertilizer (AGH-Ringer) } \\
\hline & Mixed amount (g) & Mix ratio $(\%)$ & Mixed amount (g) & Mix ratio (\%) \\
\hline $\mathrm{NH}_{4} \mathrm{NO}_{3}$ & 633 & 63.3 & 633 & 49.7 \\
\hline $\mathrm{KH}_{2} \mathrm{PO}_{4}$ & 176 & 17.6 & 176 & 13.8 \\
\hline $\mathrm{Mg}\left(\mathrm{NO}_{3}\right)_{2} \cdot 6 \mathrm{H}_{2} \mathrm{O}$ & 176 & 17.6 & 176 & 13.8 \\
\hline Fe-EDTA (Fe: 13\%) & 2.11 & 0.21 & 2.11 & 0.17 \\
\hline $\mathrm{H}_{3} \mathrm{BO}_{3}$ & 0.70 & 0.07 & 0.70 & 0.05 \\
\hline $\mathrm{CuSO}_{4} \cdot 5 \mathrm{H}_{2} \mathrm{O}$ & 0.05 & 0.005 & 0.05 & 0.003 \\
\hline $\mathrm{ZnSO}_{4} \cdot 7 \mathrm{H}_{2} \mathrm{O}$ & 11.3 & 1.13 & 11.3 & 0.88 \\
\hline $\mathrm{MnSO}_{4} \cdot \mathrm{H}_{2} \mathrm{O}$ & 0.49 & 0.05 & 0.49 & 0.04 \\
\hline $\mathrm{Na}_{2} \mathrm{MoO}_{4} \cdot 2 \mathrm{H}_{2} \mathrm{O}$ & 0.06 & 0.006 & 0.06 & 0.004 \\
\hline $\mathrm{C}_{6} \mathrm{H}_{8} \mathrm{O}_{6}($ vitamin $\mathrm{C})$ & - & - & 275 & 21.57 \\
\hline Sum & 1000 & 100 & 1275 & 100 \\
\hline
\end{tabular}

\section{Mineral content of leaves}

Three weeks after seedling transplantation, when lettuce showed maximum growth and yield, body absorption pattern and bioavailability were measured by ICP analysis. The contents of 16 inorganic ions $(\mathrm{Ca}, \mathrm{Zn}, \mathrm{Fe}, \mathrm{Cu}, \mathrm{Se}, \mathrm{K}, \mathrm{Mg}$, $\mathrm{Mn}, \mathrm{B}, \mathrm{Mo}, \mathrm{Na}, \mathrm{Co}, \mathrm{P}, \mathrm{S}, \mathrm{Cr}$ ) and four heavy metals (As, Cd, $\mathrm{Hg}, \mathrm{Pb}$ ) in the lettuce samples were measured three times and their average values were used for ICP analysis.

\section{Statistical analysis}

The data were statistically evaluated using Duncan's multiple range tests after one-way ANOVA using SPSS $12.0 \mathrm{~K}$ for Windows (SPSS Inc., Chicago, IL, USA). Statistically significant differences were considered at the $p<0.05$ level.

\section{Results and discussion \\ Characterization of test fertilizer}

The composite fertilizer AGH-Ringer was manufactured based on the mineral component ratio of the conventional fertilizer $r$-Ringer, which is commonly used in agricultural fields in Korea. AGH-Ringer, which was made by simply mixing vitamin $\mathrm{C}$ with $\mathrm{r}$-Ringer, has an NPK content ratio of 18.9:14:4.0 and has non-sedimentation and water-soluble properties (Fig. 1, Table 2). The powder forms are light-brown and a pale yellow before and after dissolution, respectively. This fertilizer is similar to or the same as the conventional fertilizer in this phenotype, and it is thought that it will be convenient to use because no sediments are formed when it is dissolved in water.

\section{Analysis of soil conditions}

To determine whether the basal soil was adequate for plant growth and within the organic farming range before the experiment, $\mathrm{pH}$, organic matter, phosphate, potassium, calcium, magnesium, cation exchange capacity, and soil temperature were measured. The soil condition was: $\mathrm{pH} \mathrm{7,} \mathrm{organic} \mathrm{matter} 25 \mathrm{~g} / \mathrm{kg}$, phosphate $438 \mathrm{mg} / \mathrm{kg}$, potassium $0.37 \mathrm{cmol}+/ \mathrm{kg}$, calcium $6.5 \mathrm{cmol}+/ \mathrm{kg}$, magnesium $2.7 \mathrm{cmol}+/ \mathrm{kg}$ and EC $1.4 \mathrm{ds} / \mathrm{m}$. All except potassium were within the range of green standards (data not shown).

\section{Chemical damage}

One typical symptom of crop damage caused by fertilizer is the occurrence of tipburn. In general, lettuce is cultivated at low temperatures and low-light conditions to inhibit tipburn caused by a calcium disorder. Tipburn should be avoided because it significantly reduces the salability of the crop $[24,25]$. Therefore, to investigate the chemical damage caused by the test fertilizer, the number of tipburns per transplanted seedling was counted at the 13th day after transplanting. Considerable (29\%) tipburn damage was observed in the groups treated with high-concentration (diluted 1/500) r-Ringer, but not in any concentrations of AGH-Ringer or conventional treatments (data not shown). While tipburn is generally considered a calcium deficiency problem, symptoms may appear despite sufficient calcium supply in the soil. The problem lies in the plant's inability to move sufficient calcium to the leaves rapidly. Calcium moves from the root to the leaves of the plant with water drawn by the transpiration process. These results suggest that the reason for the lack of tipburn in the AGH-Ringer treated group is that calcium movement is facilitated by a vitamin $\mathrm{C}$-calcium complex. This means that the test fertilizer is safe for plant growth as it does not cause chemical damage. 
a

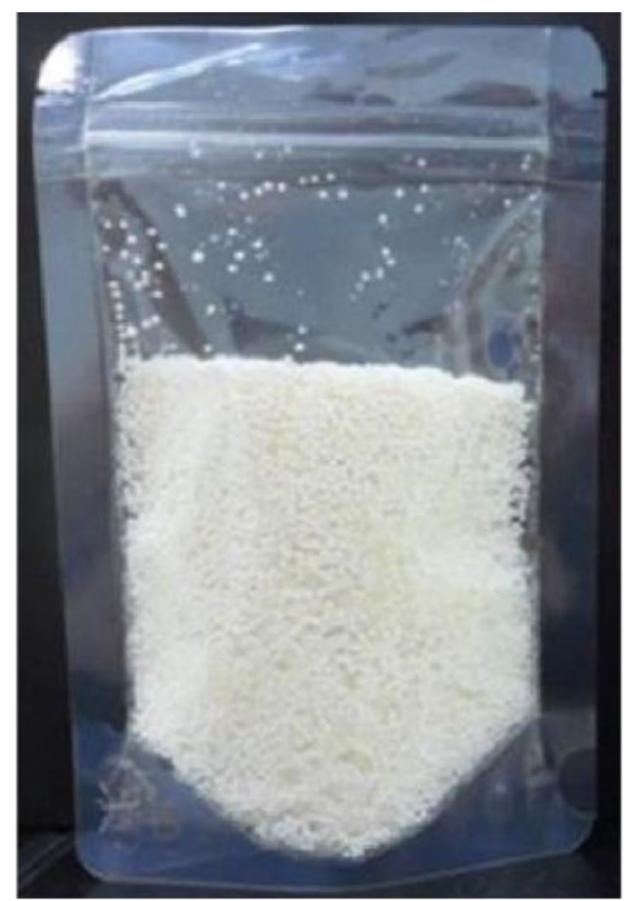

$\mathbf{a}^{\prime}$

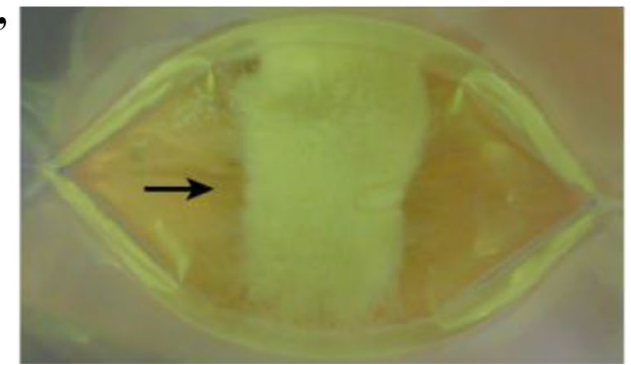

b

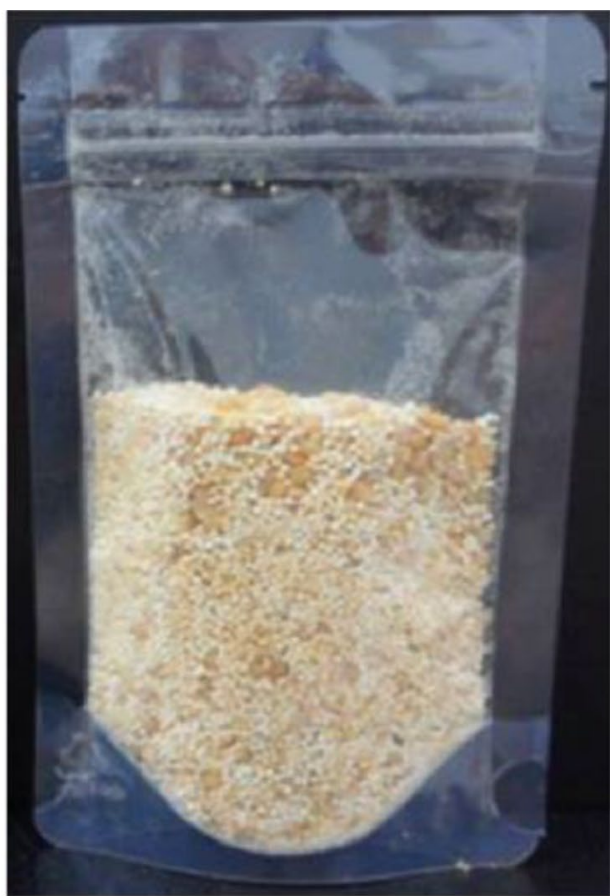

b'

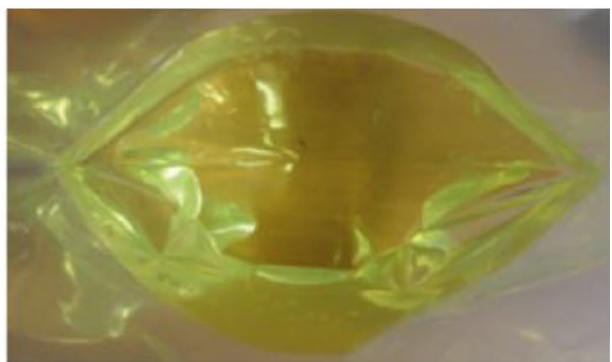

Fig. 1 The characteristics of the fertilizers on the third day after dissolving in water. Commonly used fertilizers (a, $\left.\mathbf{a}^{\prime}\right)$ used in Korea have sediments but not AGH-Ringer $\left(\mathbf{b}, \mathbf{b}^{\prime}\right)$. a, b Powder type and $\mathbf{a}^{\prime}, \mathbf{b}^{\prime}$ dissolved type. Arrow indicates the sediment in the control fertilizer $\left(\mathbf{a}^{\prime}\right)$

Table 2 Comparison of characteristics between control fertilizer and test fertilizer

\begin{tabular}{lll}
\hline Classification & Control fertilizer (r-Ringer) & Test fertilizer (AGH-Ringer) \\
\hline Fertilizer type & Composite fertilizer & Composite fertilizer \\
Appearance & White powder & Light-brown powder \\
Solubility (\%) & 12.7 & 100 \\
Sediment rate (\%) & 87.3 & 0 \\
NPK content (\%) & $18.9: 14: 4.0$ & $18.9: 14: 4.0$ \\
Method of use & Foliar or drench & Foliar or drench \\
Nutrient solution supply system & Necessary & Unnecessary \\
\hline
\end{tabular}

\section{Effects on lettuce growth}

To investigate the effects of AGH-Ringer on plant growth, growth of the aerial parts (top) and rhizosphere parts (root) were compared. Chlorophyll content was measured to compare the absorptivity and bioavailability of minerals in the plant body. In the r-Ringer groups, growth of stem diameter, leaf length, and leaf width were significantly improved when compared to the wateronly control group. Likewise, two AGH-Ringer groups (diluted 1/1000 and 1/500) showed significant increases in growth of the aerial parts and inhibition in the rhizosphere parts (Table 3). These results suggest that even 
Table 3 Effects of fertilizers on growth at harvest

\begin{tabular}{|c|c|c|c|c|c|c|c|c|}
\hline $\begin{array}{l}\text { Treatment } \\
\text { groups }\end{array}$ & $\begin{array}{l}\text { Plant height } \\
\text { (cm) }\end{array}$ & $\begin{array}{l}\text { Stem diam- } \\
\text { eter }(\mathrm{mm})\end{array}$ & $\begin{array}{l}\text { Leaf length } \\
\text { (cm) }\end{array}$ & $\begin{array}{l}\text { Leaf width } \\
(\mathrm{cm})\end{array}$ & $\begin{array}{l}\text { Leaf number } \\
\text { (ea/plant) }\end{array}$ & $\begin{array}{l}\text { Leaf diameter } \\
(\mathrm{mm})\end{array}$ & $\begin{array}{l}\text { Chlorophyll } \\
\text { (mg/g FW) }\end{array}$ & $\begin{array}{l}\text { Root length } \\
\text { (cm) }\end{array}$ \\
\hline $\begin{array}{l}\text { Control (water } \\
\text { only) }\end{array}$ & $22.1 \pm 1.6^{b}$ & $3.0 \pm 1.0^{c}$ & $12.6 \pm 1.4^{d}$ & $6.5 \pm 0.4^{b}$ & $7.7 \pm 1.2^{b}$ & $0.2 \pm 0.1^{\mathrm{a}}$ & $21.2 \pm 0.5^{\mathrm{a}}$ & $8.3 \pm 0.3^{\mathrm{a}}$ \\
\hline $\begin{array}{l}r \text {-Ringer } \\
(1 / 2000)\end{array}$ & $24.4 \pm 0.7^{\mathrm{a}}$ & $5.5 \pm 0.8^{b}$ & $16.4 \pm 0.8^{\mathrm{ab}}$ & $9.6 \pm 1.2^{\mathrm{a}}$ & $9.3 \pm 1.5^{\mathrm{ab}}$ & $0.4 \pm 0.5^{\mathrm{a}}$ & $21.3 \pm 3.1^{\mathrm{a}}$ & $8.0 \pm 0.5^{\mathrm{a}}$ \\
\hline $\begin{array}{c}\text { AGH-Ringer } \\
(1 / 2000)\end{array}$ & & $5.6 \pm 0.2^{b}$ & $14.5 \pm 1.4^{c}$ & $7.2 \pm 0.9^{b}$ & $9.0 \pm 1.0^{\mathrm{ab}}$ & $0.1 \pm 0.01^{\mathrm{a}}$ & $21.4 \pm 2.0^{a}$ & $7.8 \pm 0.6^{a}$ \\
\hline $\begin{array}{c}\text { AGH-Ringer } \\
(1 / 1000)\end{array}$ & $25.8 \pm 0.8^{\mathrm{a}}$ & $6.9 \pm 0.7^{a}$ & $17.6 \pm 0.3^{\mathrm{a}}$ & $9.6 \pm 0.2^{\mathrm{a}}$ & $11.0 \pm 1.7^{\mathrm{a}}$ & $0.1 \pm 0.01^{\mathrm{a}}$ & $23.3 \pm 7.4^{\mathrm{a}}$ & $6.8 \pm 0.5^{b}$ \\
\hline $\begin{array}{l}\text { AGH-Ringer } \\
(1 / 500)\end{array}$ & $23.7 \pm 1.2^{\mathrm{ab}}$ & $5.5 \pm 0.4^{b}$ & $15.2 \pm 0.1^{b c}$ & $7.8 \pm 0.8^{b}$ & $10.3 \pm 1.5^{\mathrm{ab}}$ & $0.2 \pm 0.01^{\mathrm{a}}$ & $20.6 \pm 1.1^{\mathrm{a}}$ & $6.5 \pm 0.9^{b}$ \\
\hline
\end{tabular}

All data are expressed as mean \pm standard deviation $(n=3)$. Different letters show a significant difference at $p<0.05$ as determined by Duncan's multiple range tests

though AGH-Ringer treatment did not induce root growth promotion, it can induce promotion of growth in the aerial parts. In other words, the body mineral absorptivity and bioavailability ability of AGH-Ringer may be better than that of r-Ringer. This was confirmed by the difference in chlorophyll contents in the plants treated by the two fertilizers. The chlorophyll content was increased by $109 \%$ by the $1 / 1000$ dilution of AGH-Ringer, but the r-Ringer groups showed similar values to the control group (Table 3). Many studies have reported that nutritional management can regulate the balance between plant reproduction and growth [26, 27]. Plant volume and tissue density are related to yield and storage period at harvest. Therefore, the effects of the AGH-Ringer on biomass and dry weight were investigated. The fresh weight of the r-Ringer groups significantly increased by a factor of more than two in both the aerial and rhizosphere parts when compared to the water-only control group. Leaf dry weight was increased significantly, but root and stem dry weights were decreased or showed no differences (Table 4). In the comparison between $r$-Ringer and AGHRinger treated groups, only the 1/1000-dilution groups showed significantly increased fresh and dry weights, and there were no differences in the other fertilizer concentration groups (Table 4). The chelated minerals promote movement of minerals from root to leaf [11]. Therefore, the improvement of growth in the aerial parts and increased stem weights can be attributed to the easy movement of minerals caused by chelation with vitamin C. Taken together, these results demonstrate that the effectiveness of fertilizer using vitamin $\mathrm{C}$ as substrate is excellent in promoting plant growth. AGH-Ringer is expected to increase the yield and production of highquality lettuce.

\section{Effect on lettuce yield}

Lettuce is cultivated at low temperatures to reduce damage, such as tipburn, caused by high temperatures. Therefore, to investigate the effects of AGH-Ringer on lettuce yield, yields were investigated for 15 weeks after transplantation, during both an inadequate low-temperature period (weeks $1-7,10.3-12.1{ }^{\circ} \mathrm{C}$ ) and a suitable lowtemperature period (weeks $8-15,14.6-18{ }^{\circ} \mathrm{C}$ ), based on ground temperature. As a result, the yield during the whole harvest period increased by $127 \%$ in the case of r-Ringer and increased by $144-157 \%$ in the case of AGH-Ringer (Table 5). At the beginning of the harvest, the yield of lettuce increased by $151-174 \%$ compared to

Table 4 Effects of fertilizers on tissue density at harvest

\begin{tabular}{|c|c|c|c|c|c|c|}
\hline \multirow[t]{2}{*}{ Treatment groups } & \multicolumn{2}{|l|}{ Root } & \multicolumn{2}{|l|}{ Stem } & \multicolumn{2}{|l|}{ Leaf } \\
\hline & $\begin{array}{l}\text { Fresh weight } \\
\text { (g/plant) }\end{array}$ & $\begin{array}{l}\text { Dry weight } \\
\text { (g/plant) }\end{array}$ & $\begin{array}{l}\text { Fresh weight } \\
\text { (g/plant) }\end{array}$ & $\begin{array}{l}\text { Dry weight } \\
\text { (g/plant) }\end{array}$ & $\begin{array}{l}\text { Fresh weight } \\
\text { (g/plant) }\end{array}$ & $\begin{array}{l}\text { Dry weight } \\
\text { (g/plant) }\end{array}$ \\
\hline Control (water only) & $0.5 \pm 0.01^{b}$ & $0.07 \pm 0.01^{c}$ & $0.1 \pm 0.1^{c}$ & $0.01 \pm 0.001^{b}$ & $5.80 \pm 0.8^{c}$ & $0.40 \pm 0.1^{c}$ \\
\hline r-Ringer (1/2000) & $1.0 \pm 0.2^{\mathrm{a}}$ & $0.13 \pm 0.03^{\mathrm{ab}}$ & $0.3 \pm 0.1^{b c}$ & $0.01 \pm 0.001^{b}$ & $12.9 \pm 5.0^{b}$ & $0.70 \pm 0.2^{b}$ \\
\hline AGH-Ringer (1/2000) & $0.9 \pm 0.1^{\mathrm{a}}$ & $0.1 \pm 0.01^{b}$ & $0.2 \pm 0.1^{b c}$ & $0.01 \pm 0.001^{b}$ & $10.9 \pm 1.6^{b c}$ & $0.60 \pm 0.1^{b}$ \\
\hline AGH-Ringer (1/1000) & $1.1 \pm 0.2^{\mathrm{a}}$ & $0.2 \pm 0.03^{\mathrm{a}}$ & $0.6 \pm 0.02^{\mathrm{a}}$ & $0.04 \pm 0.001^{\mathrm{a}}$ & $19.2 \pm 3.8^{\mathrm{a}}$ & $1.20 \pm 0.2^{\mathrm{a}}$ \\
\hline AGH-Ringer (1/500) & $1.0 \pm 0.1^{\mathrm{a}}$ & $0.1 \pm 0.02^{\mathrm{ab}}$ & $0.3 \pm 0.1^{b}$ & $0.02 \pm 0.01^{b}$ & $13.0 \pm 2.0^{b}$ & $0.90 \pm 0.1^{b}$ \\
\hline
\end{tabular}


Table 5 Effect of fertilizers on the lettuce yield in harvest periods

\begin{tabular}{|c|c|c|c|c|c|c|}
\hline \multirow[t]{2}{*}{ Treatment groups } & \multicolumn{2}{|c|}{ Weeks $1-7\left(14.6-18^{\circ} \mathrm{C}\right)$} & \multicolumn{2}{|c|}{ Weeks 8-15 (10.3-12.1 $\left.{ }^{\circ} \mathrm{C}\right)$} & \multicolumn{2}{|l|}{ Total } \\
\hline & Total yield (g/plant) & Yield rate (\%) & Total yield (g/plant) & Yield rate (\%) & Yields (g/plant) & Yield rate $(\%)$ \\
\hline Control (water only) & 89.9 & 100 & 47.7 & 100 & 137.6 & 100 \\
\hline r-Ringer (1/2000) & 120.8 & 134 & 54.5 & 114 & 175 & 127 \\
\hline AGH-Ringer (1/2000) & 154.7 & 172 & 61.7 & 129 & 216.4 & 157 \\
\hline AGH-Ringer (1/1000) & 136.1 & 151 & 61.4 & 129 & 197.6 & 144 \\
\hline AGH-Ringer (1/500) & 156.5 & 174 & 58.2 & 122 & 214.7 & 156 \\
\hline
\end{tabular}

Total crop yield in each soil temperature condition was calculated as the sum of the average ( $\mathrm{g} / \mathrm{plant}$ ) of 16 seedlings in every week

the control group and the highest value was $174 \%$ at the highest AGH-Ringer concentration (1/500). On the other hand, in the inadequate low-temperature period, the rate of increase was $122-129 \%$, which was much lower than that of the adequate low-temperature period. These results show that treatment with fertilizers has effect on crop yield. The effect of AGH-Ringer is greater than that of $r$-Ringer in the increase of lettuce harvest in both suitable low-temperature and inadequate low-temperature conditions. This result also can be attributed to increased movement of minerals due to chelation with vitamin $\mathrm{C}$ in AGH-Ringer. In addition, AGH-Ringer is expected to have low-temperature resistance and maintain yields even in inadequate cold conditions.

\section{Evaluation of mineral contents of lettuce leaves}

To determine whether the AGH-Ringer affected plant mineral absorption and bioavailability, we carried out ICP analysis on the mineral contents in harvested leaves.
When the 20 minerals were examined, the total amount detected was the lowest $(53,203 \mathrm{ppm})$ in the r-Ringer treated group, and the AGH-Ringer groups showed significantly higher values than the control group, which increased in a concentration-dependent manner. In case of r-Ringer, $\mathrm{Zn}, \mathrm{Fe}, \mathrm{S}$, and $\mathrm{Cr}$ were increased compared to the control group, and AGH-Ringer (diluted 1/2000) showed an increase in all minerals except Fe and P. Additionally, other concentrations of AGH-Ringer led to similar patterns (Table 6). These results show that $r$-Ringer exhibits typical inorganic fertilizer characteristics, but AGH-Ringer has greater efficacy than r-Ringer in mineral bioavailability and absorption through its organic functions because chelating minerals with vitamin $\mathrm{C}$ improves movement of minerals from root to leaf, and increases absorption into the plant body. Additionally, this result supports the results of previous experiments on growth promotion and increase of yield though AGHRinger treatment. Therefore, fertilizers that have organic

Table 6 Mineral contents in harvested leaves

\begin{tabular}{|c|c|c|c|c|c|}
\hline Minerals & Control (water only) & r-Ringer $(1 / 2000)$ & AGH-Ringer (1/2000) & AGH-Ringer $(1 / 1000)$ & AGH-Ringer $(1 / 500)$ \\
\hline $\mathrm{Ca}$ & $7143 \pm 13^{c}$ & $7045 \pm 21^{d}$ & $7706 \pm 5^{b}$ & $7032 \pm 23^{d}$ & $7845 \pm 9.46^{a}$ \\
\hline Zn & $37 \pm 0.11^{e}$ & $41 \pm 0.12^{d}$ & $51 \pm 0.16^{a}$ & $44 \pm 0.31^{c}$ & $45 \pm 0.31^{b}$ \\
\hline $\mathrm{Fe}$ & $255 \pm 2.17^{c}$ & $335 \pm 1.21^{\mathrm{a}}$ & $172 \pm 0.33^{e}$ & $196 \pm 0.85^{d}$ & $304 \pm 1.48^{b}$ \\
\hline $\mathrm{Cu}$ & $0.31 \pm 0.02^{b}$ & $0 \pm 0^{c}$ & $1.13 \pm 0.06^{\mathrm{a}}$ & $0 \pm 0^{c}$ & $0.25 \pm 0.05^{b}$ \\
\hline Se & $0 \pm 0^{\mathrm{a}}$ & $0 \pm 0^{\mathrm{a}}$ & $0 \pm 0^{\mathrm{a}}$ & $0 \pm 0^{\mathrm{a}}$ & $0 \pm 0^{\mathrm{a}}$ \\
\hline K & $40,953 \pm 146^{c}$ & $35,549 \pm 58^{d}$ & $43,048 \pm 148^{b}$ & $45,822 \pm 127^{a}$ & $45,811 \pm 225^{\mathrm{a}}$ \\
\hline Mg & $2095 \pm 7.06^{d}$ & $2034 \pm 5.93^{e}$ & $2228 \pm 6.99^{c}$ & $2291 \pm 24.2^{b}$ & $2356 \pm 2.69^{a}$ \\
\hline $\mathrm{Mn}$ & $13 \pm 0.02^{d}$ & $13 \pm 0.03^{d}$ & $17 \pm 0.05^{c}$ & $18 \pm 0.07^{b}$ & $27 \pm 0.19^{a}$ \\
\hline B & $20 \pm 0.12^{c}$ & $19 \pm 0.06^{d}$ & $25 \pm 0.17^{b}$ & $31 \pm 0.22^{\mathrm{a}}$ & $20 \pm 0.03^{c}$ \\
\hline Mo & $0 \pm 0^{\mathrm{a}}$ & $0 \pm 0^{\mathrm{a}}$ & $0 \pm 0^{\mathrm{a}}$ & $0 \pm 0^{\mathrm{a}}$ & $0 \pm 0^{\mathrm{a}}$ \\
\hline $\mathrm{Na}$ & $2039 \pm 12^{d}$ & $1439 \pm 3^{e}$ & $2230 \pm 0.32^{c}$ & $2494 \pm 4^{d}$ & $2308 \pm 9.0^{a}$ \\
\hline Co & $0 \pm 0^{\mathrm{a}}$ & $0 \pm 0^{\mathrm{a}}$ & $0 \pm 0^{\mathrm{a}}$ & $0 \pm 0^{\mathrm{a}}$ & $0 \pm 0^{\mathrm{a}}$ \\
\hline$P$ & $6465 \pm 28^{b}$ & $4632 \pm 12^{e}$ & $6364 \pm 11^{c}$ & $5306 \pm 17^{d}$ & $6807 \pm 49^{\mathrm{a}}$ \\
\hline S & $1873 \pm 10^{c}$ & $2051 \pm 14^{b}$ & $2076 \pm 11^{b}$ & $1548 \pm 15^{d}$ & $2119 \pm 20^{a}$ \\
\hline $\mathrm{Cr}$ & $39.6 \pm 0.15^{e}$ & $44.9 \pm 0.2^{d}$ & $53.8 \pm 0.14^{\mathrm{a}}$ & $46.6 \pm 0.29^{c}$ & $48.7 \pm 0.55^{b}$ \\
\hline Sum & $60,933 \pm 219$ & $53,203 \pm 115$ & $63,972 \pm 183$ & $64,829 \pm 213$ & $67,691 \pm 318$ \\
\hline
\end{tabular}


functions due to vitamin $\mathrm{C}$ as a substrate may be better than existing inorganic fertilizers in terms of plant growth, yield, and mineral bioavailability.

\section{Conclusions}

Straight fertilizers are very convenient to use when a farm is equipped with proper facilities. However, the preparation and use of these facilities requires a lot of money. In addition, nutrient fertilizers, which are compounds of inorganic ions, form sediments by ionic reaction when dissolved in water, and these sediments cause damage to plant growth and yield. Therefore, we developed a better fertilizer, which is no different in mineral composition than conventional fertilizer, by simply mixing conventional fertilizer with vitamin $C$. Vitamin $C$ is the richest water-soluble oxidized substance in plant cells, and has ability to chelate and bond with minerals due to the $-\mathrm{OH}$ group it contains. The vitamin $\mathrm{C}$-substrate straight fertilizer developed here, AGH-Ringer, has chelated minerals that easily move from root to leaves and had no sedimentation even when stored a long time after it was dissolved (Tables 1, 2, Fig. 1). Therefore, when lettuce was cultivated with this fertilizer, plant growth was enhanced by the minerals chelated with vitamin $C$ (Table 3 ). It was also demonstrated that its mineral bioavailability and absorption are superior to conventional fertilizers (Tables 4, 6). For these reasons, there was an increase in crop yield (Table 5). Based on these results, AGH-Ringer is expected to increase famers' profits by increasing the yield of high-quality crops and convenience of use.

\section{Authors' contributions \\ Study conception and design- $-\mathrm{H}-\mathrm{JN}$, WSS and H-HC. Acquisition of data- $\mathrm{H}-\mathrm{SC}, \mathrm{H}-\mathrm{JN}$, WSS. Analysis and interpretation of data- $\mathrm{H}-\mathrm{SC}, \mathrm{H}-\mathrm{JN}$. Drafting of manuscript: critical revision-H-SC. All authors read and approved the final manuscript.}

\section{Author details}

${ }^{1}$ HANIL BIOMED Inc., Gwangju 62363, Korea. ${ }^{2}$ MEDINUTROL Co. Ltd., Yeonggwang-gun 57024, Korea.

\section{Acknowledgements}

This research was supported by Advanced Production Technology Development Program, Ministry of Agriculture, Food and Rural Affairs.

\section{Competing interests}

The authors declared that they have no competing interests.

\section{Availability of data and materials}

This manufactured fertilizer (AGH-Ringer) has equivalent mineral contents to general fertilizer and functions that increase mineral absorption and promote plant growth in lettuce. This fertilizer also provides convenience of use because there is no sedimentation. Therefore, we expect field application of this fertilizer will increase farmer's profitability.

\section{Consent for publication}

All authors (Hyo-Seok Chae, Hye-Ji Noh, Woo Seung Song and Hyang-Hyun Cho) agreed to publication of the manuscript to this journal (Chemical and Biological Technologies in Agriculture).
Ethics approval and consent to participate Not applicable.

\section{Funding}

Advanced Production Technology Development Program, Ministry of Agriculture, Food and Rural Affairs.

\section{Publisher's Note}

Springer Nature remains neutral with regard to jurisdictional claims in published maps and institutional affiliations.

Received: 19 July 2017 Accepted: 23 December 2017

Published online: 07 February 2018

\section{References}

1. Barbosa GL, Almeida Gadelha FD, Kublik N, Proctor A, Reichelm L, Weissinger $E$, et al. Comparison of land, water, and energy requirements of lettuce grown using hydroponic vs. conventional agricultural methods. Int J Environ Res Public Health. 2015;12:6879-91.

2. Brechner M, Both AJ. Hydroponic lettuce handbook. Cornell University CEA Program. 1996; 48.

3. Beneduzi A, Ambrosini A, Passaglia LMP. Plant growth-promoting rhizobacteria (PGPR): their potential as antagonists and biocontrol agents. Genet Mol Biol. 2012;35:1044-51.

4. Franche C, Lindström K, Elmerich C. Nitrogen-fixing bacteria associated with leguminous and non-leguminous plants. Plant Soil. 2009;321:35-59.

5. Tuchy L, Chowańska J, Chojnacka K. Seaweed extracts as biostimulants of plant growth: review. Chemik. 2013;67:636-41.

6. Nakano Y, Fujitani K, Kurihara J, Ragan J, Usui-aoki K, Shimoda L, et al. Mutations in the novel membrane protein spinster interfere with programmed cell death and cause neural degeneration in Drosophila melanogaster. Mol Cell Biol. 2001;21:3775-88.

7. Bamsey M, Graham T, Thompson C, Berinstain A, Scott A, Dixon M. Ion-specific nutrient management in closed systems: the necessity for ion-selective sensors in terrestrial and space-based agriculture and water management systems. Sensors (Switzerland). 2012;12:13349-92.

8. Voogt W. Fertigation in greenhouse production. Proceedings of International Symposium on Fertigation, Beijing, China. 2005; p. 116-29.

9. Marschner H. Mineral nutrition of higher plants. 2nd ed. London: Academic Press; 1995.

10. Behnia R, Clark DA, Carter AG, Clandinin TR, Desplan C. Processing properties of ON and OFF pathways for Drosophila motion detection. Nature. 2014;512:427-30. https://doi.org/10.1038/nature13427.

11. Zacchini M, Pietrini F, Mugnozza G, Iori V, Pietrosanti L, Massacci A. Metal tolerance, accumulation and translocation in polar and willow clones treated with cadmium in hydroponics. Water Air Soil Pollut. 2009;197:2334. https://doi.org/10.1007/s11270-008-9788-7.

12. Smirnoff $N$. The function and metabolism of ascorbic acid in plants. Ann Bot. 1996;78:661-9.

13. Lee CK. Effects of selenium supplying methods on the growth and se uptake of hydroponically grown tomato plants. J Bio-Environ Control. 2005;14(4):284-8.

14. Yoon BY. Development of beef cattle feed additive for stress diminution and enhancement of marbling by using $\mathrm{Zn}$-Vit $\mathrm{C}$ chelated compound. IPET Report No. 11-1541000-001487-01:5-15; 2010.

15. Alkhader AMF, Abu Rayyan AM. Improving water use efficiency of lettuce (Lactuca sativa L.) using phosphorous fertilizers. Springerplus. 2013; 2:563. http://www.pubmedcentral.nih.gov/articlerender.fcgi?artid=3825228\&.to $\mathrm{ol}=$ pmcentrez\&rendertype $=$ abstract.

16. Bower CA, Wilcox LV. Soluble salts. In: Balck C, editor. Methods of soil analysis. Part 2. Chemical and microbiological properties Agronomy 9. Madison: American Society of Agronomy; 2010. p. 933-51.

17. Chapman HD. Cation-exchange capacity. In: Balck C, editor. Methods of soil analysis. Part 2. Chemical and microbiological properties. Agronomy 9. Madison: American Society of Agronomy; 1965. p. 891-900. 
18. Day TR. Particle size analysis. In: Balck C, editor. Methods of soil analysis. Part 2. Chemical and microbiological properties. Agronomy 9. Madison: American Society of Agronomy; 1965. p. 562-6.

19. Allison LE. Organic carbon. In: Balck C, editor. Methods of soil analysis. Part 2. Chemical and microbiological properties. Agronomy 9. Madison: American Society of Agronomy; 1965. p. 1376-8.

20. Allison LE. Moodie CD Carbonates. In: Balck C, editor. Methods of soil analysis. Part 2. Chemical and microbiological properties Agronomy 9. Madison: American Society of Agronomy; 1965. p. 1379-96.

21. Brechner M, Both AJ (1996) Hydroponic lettuce handbook. Cornell University of CEA Program 48

22. Olsen SR, Dean LA. Phosphorus. In: Balck C, editor. Methods of soil analysis. Part 2. Chemical and microbiological properties. Agronomy 9. Madison: American Society of Agronomy; 1965. p. 1035-48.

23. Pratt PF. Potassium. In: Balck C, editor. Methods of soil analysis. Part 2. Chemical and microbiological properties. Agronomy 9. Madison: American Society of Agronomy; 1965. p. 1022-30.
24. Frantz JM, Ritchie G, Cometti NN, Robinson J, Bugbee B. Exploring the limits of crop productivity: beyond the limits of tipburn in lettuce. J Am Soc Hortic Sci. 2004;129:331-8.

25. Cossio MLT, Giesen LF, Araya G, Pérez-Cotapos MLS, Vergara RL, Manca M, et al. Ten years of hydroponic lettuce research. Uma ética para quantos?. 2012;XXXIII:81-7. http://www.ncbi.n/m.nih.gov/ pubmed/15003161\%5Cnhttp://cid.oxfordjournals.org/lookup/ doi/10.1093/cid/cir991\%5Cnhttp://www.scielo.cl/pdf/udecada/ v15n26/art06.pdf\%5Cnhttp://www.scopus.com/inward/record. url?eid=2-s2.0-84861150233\&partnerlD=tZOtx3y1.

26. Roman G, Endo K, Zong L, Davis RL. P[Switch], a system for spatial and temporal control of gene expression in Drosophila melanogaster. Proc Natl Acad Sci USA. 2001;98:12602-7.

27. Kanai S, Ohkura K, Adu-Gyamfi JJ, Mohapatra PK, Nguyen NT, Saneoka $\mathrm{H}$, et al. Depression of sink activity precedes the inhibition of biomass production in tomato plants subjected to potassium deficiency stress. J Exp Bot. 2007;58:2917-28.

\section{Submit your manuscript to a SpringerOpen ${ }^{\circ}$ journal and benefit from:}

- Convenient online submission

- Rigorous peer review

- Open access: articles freely available online

- High visibility within the field

- Retaining the copyright to your article

Submit your next manuscript at $\boldsymbol{\nabla}$ springeropen.com 